\title{
Mortgaging the Future for the Present? To Buy or Not to Buy a 2-Family House Parts A, B, C
}

\author{
Herbert Sherman, Brooklyn - Long Island University \\ Daniel J. Rowley, University of Northern Colorado
}

\section{Part A}

"Figures don't lie but liars figure, that is what I always say." Stephen Hodgetts sat in front of his laptop in August of 2007 and was furiously pounding at his key board. He was entering data in an Excel spreadsheet while Yolanda Joseph, his real estate broker, was standing over his shoulder verifying the figures. When the calculations were done, Hodgetts just kept staring at the numbers. He was waiting perhaps for inspiration to strike, or even for a heavenly voice to tell him what to do. "Calculating the revenues and costs are easy" he thought to himself "but making a decision as to what to do next, well that is another matter entirely."

\section{In the Beginning...}

While pondering the purchase of a two family home as an investment property, Stephen Hodgetts reflected back as to how he had gotten into the real estate rental market in the first place. It was August 2002, and the Dow Jones Industrial Average had dipped under 8000. Richard Davis (friend, long-time colleague and fellow college professor, and mostly recently coauthor) had decided that he needed to take control of his own economic fate. Davis had done enough preliminary research on the real estate market in his own area to convince Hodgetts that there was money to be made in becoming landlords; against Hodgetts' preliminary objections.

D \& H Management, LLC, was formed and immediately acquired six homes. Davis and Hodgetts realized that they needed to raise additional funds for investment purposes and decided that if they finished off the basements of their rental properties they could re-mortgage those properties and pull out an additional $\$ 10,000-\$ 20,000$ per home. In an attempt to "double profit" from their venture, they formed a construction company, DHR Construction, LLC. In January 2003 they hired one of their renters to finish off all of the basements.

One of Davis' students, the individual who was designing their basements, thought that Davis and Hodgetts could cut out the middle man if they built their own homes. Davis and Hodgetts were convinced that backward integrating their operation by building homes to be purchased by D \& H Management as rentals, as well as for public consumption, was a good idea. Given the strength of the local housing market in May 2003, they broke ground on their first construction site in the St. Andrews development.

By January 2004, they had completed three homes at St. Andrews. By April of 2004 Davis and Hodgetts had built three homes in another development (Florence), with plans to build five more in that area. Unfortunately the Florence developer did not pay 
his landscapers and each of the properties that were owned by Davis and Hodgetts received mechanic's liens for $\$ 450,000$ per property. This made building homes on this property economically unfeasible.

Concurrently Davis and Hodgetts formed a third firm in the summer of 2004. DHR Patio Homes, LLC, was created in order to work on their latest construction project, Mountain Trails. (See Figure 1, Organizational Chart, below.) This was a large and challenging project for Davis and Hodgetts in that it involved building nearly forty custom homes in an upscale community. They built several speculative custom homes in the summer of 2005; however the real estate slowdown in summer of 2006 (Hagerty and Corkery, 2006) found Davis and Hodgetts still sitting on several homes. They were cash poor and experienced negative cash flows from having to pay off construction loans, land purchases, and home mortgages.

\section{Figure 1 \\ Davis and Hodgetts' Businesses}

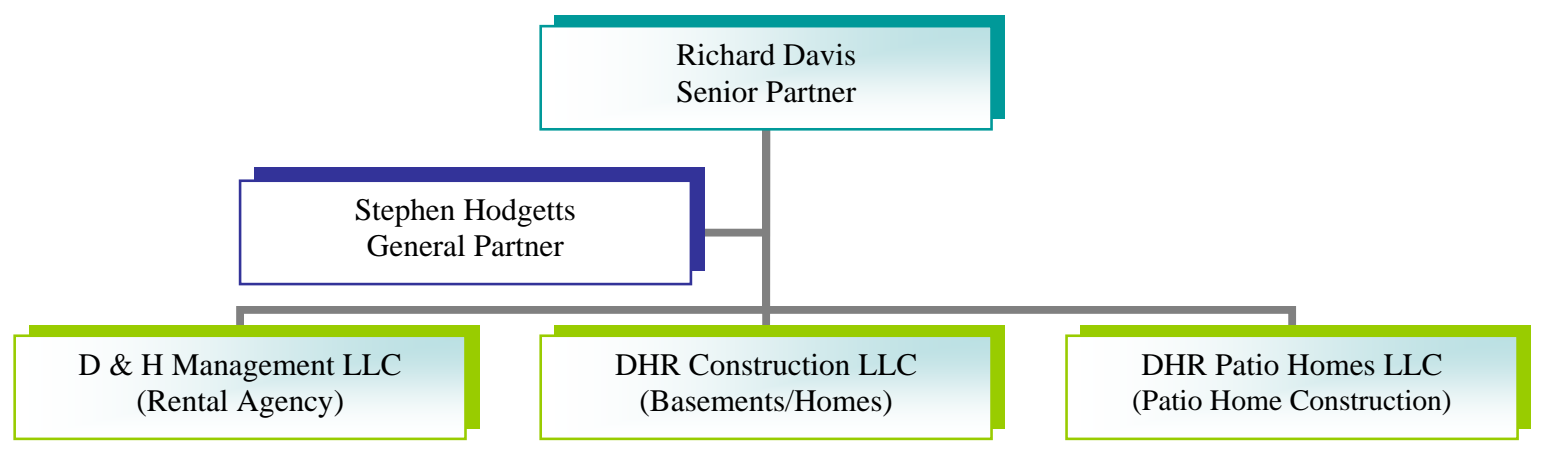

Davis and Hodgetts were forced to offset losses from their construction firm with gains from their rental units. This was an extremely worrisome situation for Davis and Hodgetts since they had both personally signed for property loans of over $\$ 2,000,000$. In order to secure these loans they had pledged their personal assets. If the loans could not be repaid, then either the payments would have to come out of their own pockets or their remaining assets (including their personal residences) would have to be liquidated. Davis was in particular personal financial trouble, having built two additional speculation homes on his own in a market that became heavily saturated with existing home sales. Neither of his homes received much foot traffic and neither home had been bid upon. All of this information was fermenting in Hodgetts' head as he contemplated this latest business deal.

\section{A Vacation Turns Serious}

Hodgetts did not start out looking for a "deal of a life time" (as he called it) when he was visiting his friend Sharon Kirchoff in the summer of 2007 in what he considered remote Montana. Kirchoff had become a lecturer in Physics at Carroll College in the small town of Helena (estimated population in 2003 was 26,718; per capita income as of 1999 was 
slightly over $\$ 20,000$ ) (Anonymous, 2007), ironically the capital, (see Figure 2, map below). She had purchased a large 3000 plus square foot Victorian home for slightly over $\$ 100,000$, just below

Figure 2 (Anonymous, 2007) Northwestern United States Map Featuring Helena, Montana



the mean value of homes in the town. (Anonymous, 2007) Hodgetts had fallen in love with the town of Helena in that it had a real small town feel yet, being a college town and the capital; it had most of the amenities of larger cities. He had a real passion for the mountains and the great outdoors, and Helena certainly had its share of parks, camping, and outdoor recreation. Hodgetts also loved snow, winters, and cool, dry summer weather. Hodgetts kept thinking that this would be a great place to retire, or just spend the summers.

However, what really fascinated Hodgetts was the cost of living. Rents were quite low (around $\$ 400 /$ month for a 2 bedroom apartment, less than $1 / 2$ the cost of his area) and the cost of staples were lower as well. Being the ever intrepid entrepreneur, he investigated the housing market and found that the homes were relatively low cost in relation to his own home town. In Helena $\$ 100,000$ would buy a decent 2000 square foot, land-locked home while water exposures ran two to three times higher. In comparison, "starter" homes in his area (a basic three bedroom, 2 bath house; around 1300 square feet) were going for about $\$ 230,000$. Starter custom patio homes that he built through his business sold for about $\$ 400,000$.

\section{An Idea Turns to Action}


Kirchoff was keen to point out to Hodgetts that homes were readily available for purchase and that the housing market had really cooled off since she had purchased her home back in 2005. Hodgetts noticed, as they walked around town, that at least one out of every five homes was up for sale and therefore there seemed to be a real glut on the market. He also noticed that, given the low average income, few people would be able to purchase even a smaller home since they would not qualify for a mortgage. He assumed that the down payment would be at least $10 \%$ of the total purchase price (he doubted that many people earning $\$ 20,000$ a year could save a $1 / 2$ year's salary given the fact that the average savings rate of the American public was a negative $.5 \%$ as of January, 2006). There'd be plenty of homes for sale for a long time, thought Hodgetts, a great opportunity for a buyer who could find the right desperate seller who needed to sell and sell fast. A low ball price for a home might actually be taken.

More importantly, as a College town and capital, many people seemed to be renting residences. There did not, based upon what he saw in the local papers and from walking the streets, seem to be a glut in the market of available apartments. He actually saw advertisements under the topic "apartments wanted to rent." He decided, from a supply-demand perspective, buying a low-cost home for the purposes of renting might be a good investment for himself and/or his firm. Furthermore, he also could then write off, for tax purposes, any trips that he would take to Helena under the guise of investment research (including his current trip).

A plan was forming in his mind, he just needed to right business model in which to make things work out. After a lot of thought, and some soul searching, Hodgetts decided that there was real opportunity in Helena. His plan was to find a home to buy with no money down which would earn him just enough rental income to pay the mortgage and cover any other out of pocket expenses. His payback would come in the form of perhaps some long term capital appreciation (wait out the sluggishness of the market) but, more importantly, he would be building up capital in the house using other peoples' money to pay off the mortgage.

He bounced the idea off of Kirchoff who thought it was a really good suggestion. He then decided to enlist the services of a real estate broker who had helped Kirchoff buy her home.

\section{After the Fox}

Kirchoff then called up Yolanda Joseph, a real estate agent at the Moosehead Agency. This was an office affiliated with a major real estate firm (independently owned and operated) and she explained to Joseph what Hodgetts was looking for. An appointment was set for the next day, and Hodgetts explained that he might want to summer in the area and therefore a 2-family unit might be best. One unit could have a year round renter in, while the other might house college students who would be renting for the fall, winter, and spring. Ms. Joseph promised to search the multiple listings (MLS) for potential homes that would make good rental units. 
The next day Joseph showed Hodgetts several single family 2-3 bedroom residences that were for sale, anywhere from $\$ 40-80 \mathrm{k}$. The lower end homes were disastrous in that they required tons of work and looked like they hadn't been maintained for many years; these were true "handyman specials." Hodgetts was neither handy nor willing to spend what looked like tens of thousands of dollars to get these homes in shape and therefore did not give these homes a second look. He wanted something he could immediately rent and these homes were just not suitable. The higher end single family homes were very nice but he would not be able to live in them over the summer; these would be solely investment properties. However, rents ranged from around $\$ 400 /$ month for 2-bedroom homes (and the landlord paid heat) to $\$ 550 /$ month for 3-bedrooms. Using a mortgage calculator, a $\$ 60,000$ home (6.5\% for a fixed 30 year mortgage), with no money down, would have a mortgage of about \$380/month (just under the rent for a 2-bedroom apartment). An $\$ 80,000$ home's mortgage would be a little over $\$ 500 /$ month, $\$ 50$ under the rent for a 3 bedroom. Hodgetts quickly called his broker to discuss the situation.

(Hodgetts) The numbers just don't seem good enough. The rent barely covers the mortgage and we have yet to factor in closing costs, heat, insurance, taxes, a management fee, and sundry expenses (i.e., changing the locks). I could put some money down on the house but I would have to factor in an opportunity cost (around $4 \%$ - short term CD rates). However, that is what I exactly don't want to do, take money out of my own pocket.

(Joseph) I understand. It sounds like a multifamily dwelling, perhaps just a two family house, would be the way for you to go. We do not have many structures like that in our fair community, but l'll see what I can do. When these commercial properties come up for sale they fly out the door very fast because they are real money makers.

\section{Was it Fate, Kismet, Good Fortune ....or Just Dumb Luck?}

A few days went by and Hodgetts had a day or two left in his vacation before he flew back home. The buying of an investment property completely slipped his mind as he continued to enjoy the great outdoors of Helena and a relaxing vacation. As he was walking in the woods enjoying the scenery, his cell phone rang. Joseph had found the perfect 2 family house about 10 miles outside of Helena, a brand new listing, and wanted him to see it ASAP. He asked her to FAX the information over to his hotel so that he could look at it when he got back from his hike. The following material was at his hotel when he arrived (See Figures 3, 4, and 5).

\section{Figure 3}

\section{Property Description and Details of $251^{\text {st }}$ Street (Lusk, G.; n.d.)}

\section{PROPERTY DESCRIPTION}

Well maintained, clean Duplex in South Range. (See Figure 4, area map.) Each unit is 2BR/1BA with lots of space and large bedrooms. Unit 2 has a 2 nd floor front balcony and 
Unit 1 has an enclosed front porch. The large lot provides lots of off street parking and there is enough room to build a garage. Has newer furnace, some windows, water heaters, electric, bathrooms and laundry rooms. Unfinished walk-up attic provides additional cold storage space or option for finishing. Property has had a good rental history; live in the lower unit and help make your payment from the upper unit or generate income from both units. Stone and block foundation, vinyl siding, city water and sewer, full basement, forced air heat. (See Figure 5, Photos.)

\section{PROPERTY DETAILS}

Property Number: 221699; Property Type: Commercial : Multi-Family; Location: South Range

School District: Adams Township School District Square Feet: 2674 Lot Size: 75 X 100 Bedrooms: 4, Bathrooms: 2.00, Garage Capacity: 0.00 Unit 1: 4 rooms, 2 bedrooms, 1 bath, 1337 sq ft., rent $\$ 450$, includes all appliances and heat Unit 2: 4 rooms, 2 bedrooms, 1 bath, 1337 sq ft., rent $\$ 450$, includes all appliances and heat. Price: $\$ 67,000$

\section{Figure 4}

Detailed Map of Area - $251^{\text {st }}$ Street (Yahoo.com/maps, n.d.)



Figure 5

Rear Exterior and Interior Pictures of Two Family House on $251^{\text {st }}$ Street (Lusk, G.; n.d.) 


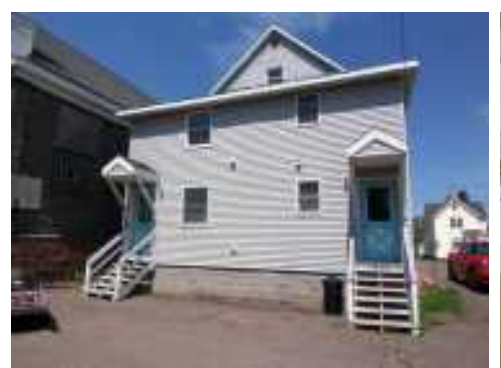

(up) Rear Entrance (dn)

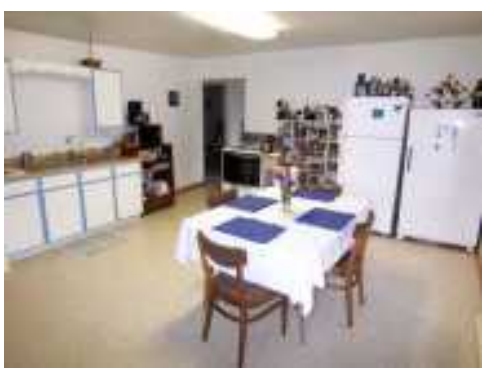

First Floor Kitchen



First Floor Bathroom

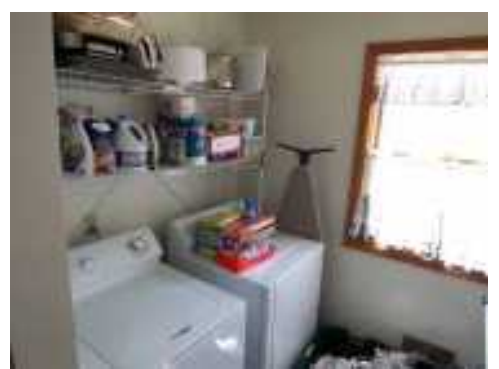

First Floor Laundry Room

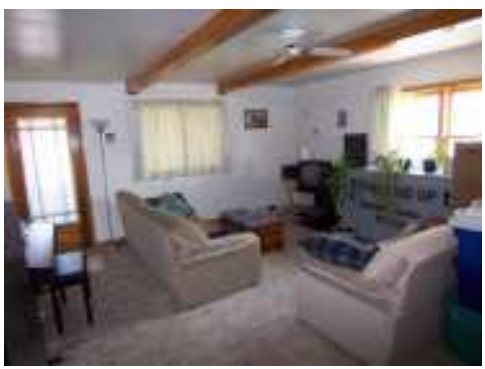

First Floor Living Room

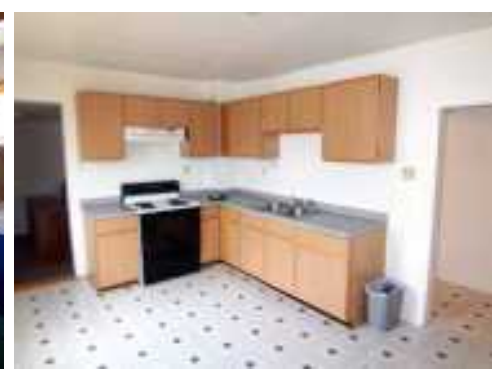

Second Floor Kitchen

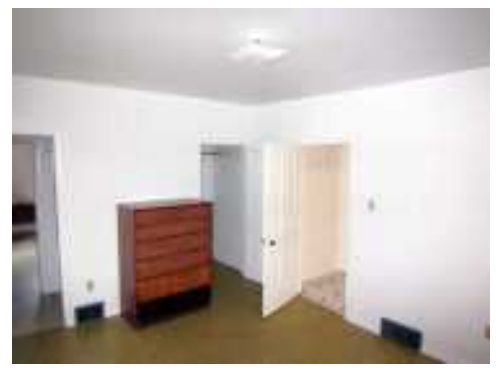

Second Floor Bedroom

\section{Living Room}
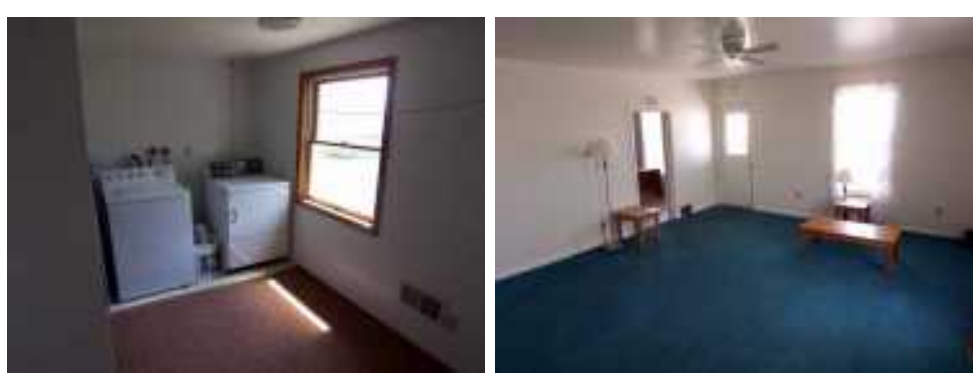

Second Floor Laundry Room Second Floor

Rather than taking a relaxing shower, Hodgetts pulled out his computer and started to make some basic calculations. See Figure 6 below:

Figure 6

Preliminary Annual P/L Statement: $251^{\text {st }}$ Street

Asking Price: $\$ 67,000$

\begin{tabular}{|l|l|l|l|}
\hline Revenues & $\underline{\text { Total }}$ & $\underline{\text { Expenses (estimated) }}$ & \\
\hline Rent @ \$900/m & $\$ \mathbf{1 0 8 0 0}$ & Taxes & $\$ 1500$ \\
\hline & & Heat & $\$ 1200$ \\
\hline & & Insurance & $\$ 600$ \\
\hline & $\begin{array}{l}\text { Management fee } \\
(@ 10 \%)\end{array}$ & $\$ 1080$ \\
\hline & $\begin{array}{l}\text { Mortgage (30 yr @ } \\
6.5 \%)\end{array}$ & $\$ 5100$ \\
\hline & Contingency (@10\%) & $\$ 1080$ \\
\hline
\end{tabular}




\begin{tabular}{|l|l|l|l|}
\hline & & Total & $\mathbf{\$ 1 0 5 6 0}$ \\
\hline Profit/Loss & $\$ 240$ & & \\
\hline
\end{tabular}

Hodgetts double-checked his figures and thought about what his next move should be.

\section{REFERENCES - PART A}

Anonymous (January 30, 2006). U.S. savings rate hits lowest level since 1933: Consumers depleting savings to buy cars, other big-ticket items Associated Press. Retrieved from http://www.msnbc.msn.com /id/11098797/, October 11, 2007.

Anonymous (October 10, 2007). Helena. Retrieved from http://www.citydata.com/us-cities/The-West/Helena.html.

Hagerty, J. R. and Corkery, M. (August 23, 2006). Housing slump proves painful for some owners and builders. 'Hard landing' on the coasts jolts those who must sell. Ms. Guth tries an auction "We're preparing for the worst". Wall Street Journal, A1.

Lusk, G. (n.d.). Property description and details of $251^{\text {st }}$ Street. Retrieved from http://www. northwindrealestate.com/ listing.php?target=99, October 10, 2007.

Yahoo.com/maps (n.d.). Detailed Map of Area $-251^{\text {st }}$ Street. Retrieved from http://maps. yahoo.com/maps_result?addr=25+First+Street\&csz=49945\&country=US, October 10, 2007.

\section{Part B}

Hodgetts thought that his basic calculations were good enough to proceed to the next step - to verify his figures with the broker. Obviously, if the numbers held up, he would then examine the premises. Ms. Joseph was quite pleased to hear from Mr. Hodgetts and sat down to go over with Hodgetts his calculations. She immediately pointed out that he would need to factor in:

a) closing costs (about $5 \%$ of the mortgage rate);

b) a higher mortgage rate because this was a commercial venture and might be considered a sub-prime mortgage (she estimated a $7 \%$ loan rate because he wanted to finance everything, including the closing costs); and

c) an additional $1 / 2$ month management fee for the first month.

Ms. Joseph then called the owner to arrange for a viewing (the owner lived on the first floor) and found out this additional information:

1 ) the upstairs renter was paying $\$ 400 /$ month because he was using the owner's lawn mower and snow blower to maintain the property. His contract lasted for another 8 months. 
2) the owner wanted to stay an additional 3 months for $\$ 400 /$ month. She wanted to take the downstairs washer/dryer, and would include in the asking price the oil in the storage tank and the lawn mower/snow blower.

Hodgetts took a walk through the property. The home looked fairly old (40-60 years old) but in good shape. The heating system was 12 years old and looked OK and the roof seemed alright from the outside. However, Hodgetts was not an engineer and didn't trust his own judgment. There seemed to be no noticeable water damage in the basement and all the rooms seemed to be in good, habitable shape; certainly better than what he had be shown before. If interested, he would have to pay an engineer $\$ 300$ for a basic engineering report to make sure the building was in ok shape.

He went back to his laptop and, with Ms. Joseph's assistance, redid his calculations. In the interim, Ms. Joseph reminded Hodgetts that he could always bid lower than the asking price and that might factor into his decision-making. She suggested an offer of $\$ 62,000$.

\section{Part C}

Hodgetts, just before he left for home, decided to make an offer of $\$ 58,000$, about $86 \%$ of the asking price. He also included in his bid the requirement that all appliances be included. Two days later the seller came back with an offer of $\$ 62,000$ but minus all of the appliances, the lawn mower, and the snow blower. Hodgetts sat on the deal for a few days to let the seller think about his offer and to allow himself, now that he as home, to rethink the deal.

Before he had made any decision, re received a call from Joseph saying that the seller was willing to accept his terms (the $\$ 58,000$ price, all appliances included). In the interim, the newspapers were printing articles about the collapse of the sub-prime lending market and much higher lending rates (i.e., 10\%). (Melsen, D., 2007) Meanwhile, Hodgetts' construction business in Colorado was seeing little activity. He and his partner were forced to take out a $\$ 150,000$ credit line in order to provide the business some needed short-term cash flow.

\section{REFERENCES - PART C}

Melsen, D. (August 7, 2007). Real estate loan market August 2007: Subprime meltdown continues. Retrieved from http://www.searchlightcrusade. net/2007/08/realestate-loan-market-august.html, October 11, 2007. 